\title{
Indefinição limítrofe e estratégias territoriais nos confins da bacia Platina
}

Uma leitura geográfica da Questão de Limites das Missões/Palmas

Neighbouring uncertainty and territorial strategies at the edge of Platina Basin:

A geographical reading of Missões/Palmas Boundary Issue

Indefinición limítrofe y estrategias territoriales en los confines de la cuenca del

Río de La Plata: Una lectura geográfica de la Cuestión de Limites de las Misiones/

Palmas

Indéfinition frontalière et stratégies territoriales dans les confins du Bassin de la Plata: Une lecture géographique de la quéstion des Missions/Palmes

\section{Cristina de Moraes}

\section{(2) OpenEdition}

Journals

Edição electrónica

URL: https://journals.openedition.org/terrabrasilis/5268

DOI: 10.4000/terrabrasilis. 5268

ISSN: 2316-7793

\section{Editora}

Rede Brasileira de História da Geografia e Geografia Histórica

Refêrencia eletrónica

Cristina de Moraes, «Indefinição limítrofe e estratégias territoriais nos confins da bacia Platina», Terra Brasilis [Online], 12 | 2019, posto online no dia 29 dezembro 2019, consultado o 05 dezembro 2022 URL: http://journals.openedition.org/terrabrasilis/5268 ; DOI: https://doi.org/10.4000/terrabrasilis 5268

Este documento foi criado de forma automática no dia 5 dezembro 2022.

All rights reserved 


\section{Indefinição limítrofe e estratégias territoriais nos confins da bacia Platina}

Uma leitura geográfica da Questão de Limites das Missões/Palmas

Neighbouring uncertainty and territorial strategies at the edge of Platina Basin: A geographical reading of Missões/Palmas Boundary Issue

Indefinición limitrofe y estrategias territoriales en los confines de la cuenca del Río de La Plata: Una lectura geográfica de la Cuestión de Limites de las Misiones/ Palmas

Indéfinition frontalière et stratégies territoriales dans les confins du Bassin de la Plata: Une lecture géographique de la quéstion des Missions/Palmes

\section{Cristina de Moraes}

\section{Introdução}

1 O presente trabalho, parte de uma pesquisa de doutoramento, ${ }^{1}$ tem como objetivo discorrer sobre a Questão de Limites das Missões/Palmas, protagonizada pela Argentina e pelo Brasil. Os litígios territoriais correspondem a eventos em que a dimensão espacial tem um papel fundamental, deste modo, são acontecimentos que podem serem analisados contemplando diferentes temáticas ou, mesmo, enfoques investigativos. Todavia, motivada pela estrutura de um artigo, optou-se por discorrer neste texto sobre as origens do litígio e parte das políticas territoriais adotadas por cada país frente a esta querela.

2 As questões limítrofes representavam a possibilidade de ampliação das posses territoriais, facilidades geoestratégicas e vantagens econômicas - algumas, de exploração imediata (como a exploração de ervais e madeiras), enquanto outras a médio prazo (comercialização de terras e potencial energético). Com a independência 
política das colônias ibéricas, emergia a possibilidade de redefinir os limites territoriais, fato que implicava em uma releitura das fronteiras e dos acordos vigentes. Para a Questão das Missões/Palmas (doravante QMP), essa retomada estava alicerçada na indefinição de um dos rios limítrofes ainda durante o reconhecimento topográfico advindo do Tratado de Madri (1750). Quando Brasil e Argentina alcançaram uma relativa estabilidade política doméstica, os dois países impulsionaram um conjunto de medidas políticas para conduzir a modernização da economia e do território. É neste contexto que a QMP se torna de primordial resolução. Mesmo ao se tratar de um evento que permite diversas análises, especificamente para este trabalho estão abordadas as temáticas acerca da origem do litígio, bem como das políticas territoriais de fronteiras desenvolvidas pelos países envolvidos.

\section{Entre o ignoto e a ambição territorial: as origens da Questão das Missões e/ou de Palmas}

3 A determinação dos limites dos estados territoriais implicou na confrontação de interesses de Estados por áreas estratégicas e/ou que estavam situadas em zonas de fronteiras de diferente jurisdição política. A definição jurídica do espaço de soberania de cada Estado pode ser indicada como componente fundamental para o desdobramento de políticas que visam à formação territorial. Portanto, corresponde a uma ação essencial para a inserção das áreas não exploradas, mas que integram o patrimônio territorial de cada Estado. Afirmar isso não significa cogitar que, até a sua definição, as áreas de soberania imprecisa ou em litígio não sejam objeto de valorização simbólica ou material. O que se considera como primordial é que esses limites sejam efetivamente reconhecidos juridicamente a nível internacional, para que cada Estado possa realizar práticas de integração territorial com maior ênfase na sua respectiva área. Somente após esse reconhecimento é que políticas territoriais de maior envergadura podem ser desenvolvidas pelos Estados.

4 Para resolver as questões relacionadas aos limites territoriais com outros países, tanto Brasil e Argentina sustentavam que seus territórios correspondiam àqueles recebidos das antigas coroas europeias no momento da ruptura da condição colonial. Todavia, o expansionismo luso-brasileiro para além do meridiano de Tordesilhas condicionou mudanças na divisão das posses iniciais, as quais foram reconhecidas por acordos posteriores (como o Tratado de Madri) e que praticamente redefiniram os limites internacionais. Deve ser considerado que mesmo com a assinatura de acordos que reconheciam as mudanças de posses advindas do expansionismo, isso não foi suficiente para dirimir dúvidas, as quais serviram para instigar desacordos que acabaram por constituir a QMP, no século XIX. Esse contexto de informações imprecisas e de ambições territoriais foi propício para a construção de um discurso fronteiriço que invalidou as antigas definições e criou condições para assegurar novas delimitações. $\mathrm{Na}$ QMP, o ponto central da argumentação dos dois Estados recaía sobre a localização dos rios divisores acordados ainda para o Tratado de Madri, a saber: o Rio Peperi e o Rio Santo Antônio. Em menor escala, apareceu a contestação em torno da toponímia da área litigiosa: enquanto os argentinos identificavam como Misiones, por compreender que a referida área correspondia às antigas Missões Jesuíticas do Paraguai, o Estado brasileiro identificava como Campos de Palmas (Rio Branco, 2005). 
5 Esse desacordo em relação à identificação dos rios limítrofes intensificava o ambiente de animosidade nutrido pelos dois Estados, visto que ambos os países se acusavam reciprocamente de efetuar uma manipulação toponímica como estratégia territorial, conforme é possível constatar na seguinte passagem:

O Império do Brasil tem mudado ultimamente estes nomes oficiais (Santo Antônio e Pepery) do século XVIII, pelos nomes de Jangada e Chapecó, como eu disse: porém, o árbitro irá notar que em nenhum documento do século XVI, XVII e XVIII, se menciona os ditos nomes, arbitrariamente introduzidos na discussão. (Zeballos, 1894: 5, tradução livre) ${ }^{2}$

6 Para os argentinos, as heranças aceitas pelo princípio de uti possidetis ${ }^{3}$ eram válidas somente para os Estados originados a partir da colonização espanhola. Para as fronteiras com o Brasil, estipulavam que a demarcação correta deveria seguir as proposições de Tordesilhas, pois os acordos firmados em Madri (1750) foram invalidados em 1761 (pelo tratado de El Pardo).

7 As temáticas centrais que constituíam as argumentações sustentadas para o litígio podem ser identificadas em três grupos. Sendo eles: a temática da toponímia, seja fluvial ou espacial, em que ambos Estados trocavam a acusação de manipulação toponímica, usando o nome dos lugares de forma estratégica. Em um segundo grupo pode ser identificado a discussão se a posse competia ao Estado que havia realizado maior povoamento na zona e em sua proximidade (argumento sustentado pelo Brasil), ou se pertencia aquela que havia recebido por direito da Coroa Ibérica (neste caso, este argumento era sustentado pela Argentina). Neste caso, a discussão versava sobre dois princípios opostos: uti posseditis ou jure de facto (recebido por direito). E por fim, como um terceiro grupo temático, é possível observar sobre a veridicidade dos mapas usados pelos Estados envolvidos para sustentar as argumentações apresentadas.

8 É importante considerar que muitos eventos transcorridos nos séculos anteriores são elementos relevantes para compreendermos as estratégias de conquista espacial que foram empregadas para afirmação de posses e serão retomados de forma pontual.

9 A interiorização das posses lusitanas para além da indicação de Tordesilhas ao longo do período colonial, especialmente no período da União das Coroas Ibéricas (1580 -1640), atribuiu uma plasticidade às fronteiras que resultou nas conquistas de largas porções de terras. Essas conquistas foram resultado de um conjunto de práticas territoriais que ampliavam a presença lusitana no continente americano e tiveram como consequência as constituições de querelas territoriais. Cabia, portanto, aos Estados latino-americanos resolvê-las.

10 Em virtude que tanto Brasil como a Argentina defendiam que as unidades espaciais herdadas da condição colonial eram as delimitações correspondentes das posses territoriais de cada Estado, houve a conservação de alguns elementos constituintes do litígio luso-hispânico, enquanto outros, contemporâneos ao período oitocentista, foram inseridos na querela. Dos antigos fatores de disputa, os quais foram recebidos como heranças coloniais e indicados como centrais nos desentendimentos, a localização dos rios limítrofes deteve um papel central. A localização exata dos rios correspondeu a um elemento importante na construção do discurso fronteiriço, nos quais as argumentações sobre a manipulação toponímica são explícitas e buscaram explorar com exaustação as próprias hipóteses defendidas. É válido salientar ainda, que ao mesmo tempo que os países almejavam validar seus próprios argumentos, objetivavam ainda, recusar as arguições discursivas do adversário. Brasil e Argentina admitiam um 
critério hidrográfico ao reconhecer que os rios Peperi e Santo Antônio eram os delimitadores das jurisdições territoriais, todavia, discordavam quanto à localização desses rios. Essa limitação advinha das decisões e explorações pertencentes ao Tratado de Madri (1750) que, embora anulado em 1761, serviu de base para a configuração dos limites internacionais das colônias ibéricas sul-americanas. 0 momento da elaboração desse tratado foi marcado pelo esforço de sistematização dos conhecimentos geográficos, dado que os processos jurídicos cada vez mais incorporavam os documentos cartográficos e as descrições geográficas para arguição. ${ }^{4}$

$11 \mathrm{O}$ avanço do conhecimento acerca das posses ultramarinas, justapostas às práticas efetivas de uso e disputas territoriais pelas mesmas, gradativamente solapou um sistema de partilhas alicerçado em linhas meridianas, fator que determinou a busca de referências mais concretas e ajustadas à realidade construída. Assim, para a preparação do Acordo de Madri, observou-se o abandono das partilhas por linhas meridianas e a construção dos limites a partir de uma base empírica, que considerava as ocupações efetivas e as fronteiras naturais:

(...) e querem que ao diante não se trate mais dela, reduzindo os limites das duas monarquias aos que se assinalaram no presente tratado; sendo o seu ânimo, que nele se atenda com cuidado a dois fins: o primeiro, e mais principal é, que se assinalem os limites dos dois domínios, tomando por balizas as paragens mais conhecidas, para que em nenhum tempo se confundam, nem deem ocasião a disputas, como são a origem, e curso dos rios, e os montes mais notáveis: o segundo, que cada parte há de ficar com o que atualmente possui; à exceção das mútuas cessões, que em seu lugar se dirão; as quais se farão por conveniência comum e para que os confins fiquem, quanto for possível, menos sujeitos a controvérsias. (Rio Branco, 2002: 82)

12 A incorporação de elementos empíricos na definição dos limites territoriais e no sistema jurídico internacional a partir de 1649, conferiu importância ainda maior à atribuição do nome aos lugares, visto que o topônimo passou a ser um elemento-chave para a definição dos limites (Kantor, 2009). Em virtude dessa incorporação, é perceptível que Portugal buscou empregar um sistema toponímico que registrasse efetivamente a sua ocupação no espaço, sobretudo quando se tratava de expansão, como é o caso da fronteira meridional situada no oeste. Como exemplo é possível mencionar a mudança na toponímia jesuítica das porções de terras situadas na América portuguesa, modificação feita com o intuito de constituir uma imagem espacial associada à posse lusa e obscurecer os vínculos com as Missões Jesuíticas. A área que era identificada de Ibituruna pelos jesuítas, posteriormente foi designada como Campos de Palmas pelos lusitanos. Essa identificação luso-brasileira passou a ser empregada a partir do Oitocentos, e aparecia tanto em documentos oficiais como nas orientações para a "Expedição Real para Conquista dos Campos de Palmas" de 1808.

13 No Tratado de Madrid, Portugal cedia para a Espanha a Colônia do Sacramento e, em contrapartida, receberia o território dos Sete Povos das Missões, ao noroeste do Continente de São Pedro. A resistência indígena frente à expulsão das Missões tornou impossível realizar os trabalhos demarcatórios (Golin, 2011) nesta área da fronteira, de modo que os limites foram acordados, mas a realidade in loco ainda estava sob condição ignota.

14 A legalidade desse acordo foi invalidada em 1761 por meio do Tratado de El Pardo. Contudo, as bases geográficas do Tratado de Madri permaneceram presentes no Tratado Preliminar de Paz e Limites de Santo Ildefonso (1777), o qual sustentava a 
necessidade de traçar limites a partir dos acidentes geográficos. Na execução desses trabalhos demarcatórios competiu para a Primeira Partilha a área que possuía como ponto inicial o Arroio Chuí “até onde o Rio Iguaçu entra no Paraná" e daí "até junto a parte inferior do Salto Grande do mesmo Paraná" 5 visando, sobretudo, reconhecer a cabeceira do Rio Santo Antônio (Cortesão, 2001: 308). Nesse trecho, devido às condições topográficas, não foi possível realizar o deslocamento dos trabalhadores da Primeira Partilha e como uma alternativa para registrar as informações, foi apenas esboçado de acordo com aquilo que acreditavam ser a sua localização no terreno.

A incerteza em relação aos acidentes geográficos e rios atribuiu certa fluidez à nomenclatura durante a execução do acordo. Isso é passível de ser constatado nos trechos das orientações para trabalhos demarcatórios que evidenciam a incerteza em relação ao conhecimento da hidrografia base para a definição dos limites. A instrução propõe buscar o rio mais próximo ou encontrar aquele rio que se imaginava ser o mais próximo. A exemplo, traz-se um trecho do Artigo $3^{\circ}$ da Instrução Especial do Tratado de Madri, de 27 de julho de 1757, que orientava os comissários e práticos a se deslocarem pelo Rio Uruguai até encontrarem, pela margem esquerda, a foz do Rio Peperi e, através dele, moverem-se até sua cabeceira - depois "inviarâõ hüa Partida que vá à pé a reconhecer pelo terreno mais alto a cabeceira principal do rio mais vezinho, que desemboque em o Yguassû" (Rio Branco, 2005: 58. Grifos nossos). O rio mais vizinho corresponde ao Santo Antônio, que na época ainda estava inominado (Figura 1). Devido às condições topográficas que dificultavam a exploração do mesmo, permaneceu inexplorado até o levantamento técnico realizado pela Comissão CientíficoDemarcatória Argentina-Brasil, em 1903.

Figura 1: Parte do Mapa das Cortes (1749)

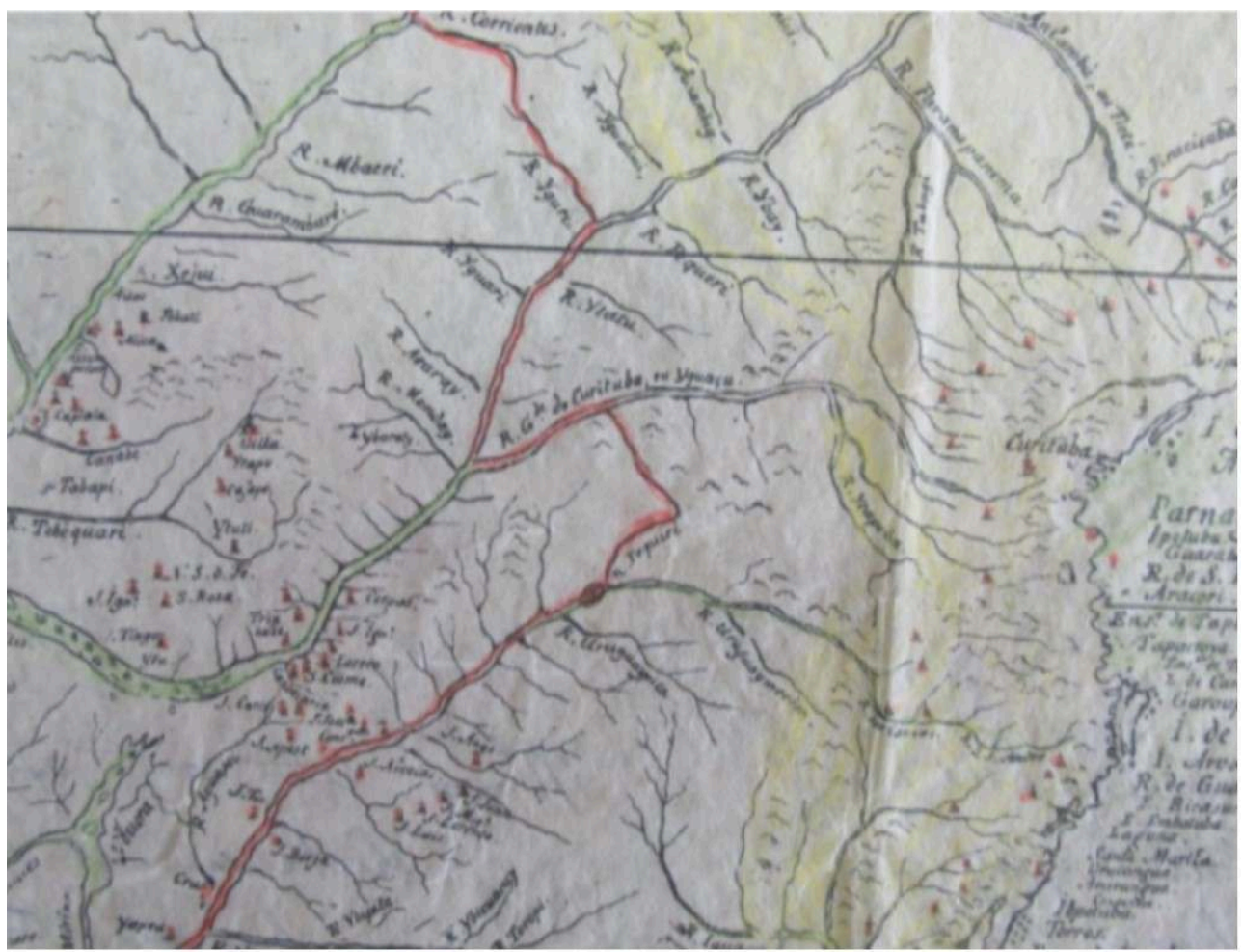

Na imagem é possível verificar a identificação "Pepiri" e o Rio Santo Antônio, mas ainda inominado Fonte: Mapoteca do Ministério das Relações Exteriores do Brasil. Rio de Janeiro, RJ 
Em 1788, uma comissão composta apenas por comissários espanhóis identificou um rio à margem direita do Rio Uruguai: “acima da confluência do Peperi-Guaçú, e, portanto, mais para Leste, dentro do território português, a foz de outro rio que já figurava, ${ }^{6}$ embora sem nome, nos mapas do comêço dêsse século" (Rio Branco, 2002: 5). Esses comissários passariam, então, a designar o atual Peperi como Peperi-Mini e nomear de Peperi-Guaçú o que hoje é o Rio Chapecó, interiorizando a fronteira em direção ao leste da bacia Platina. Essa lógica também foi aplicada na porção norte, denominando Santo Antônio-Mini o Rio Santo Antônio, enquanto o Rio Chopim passou a ser identificado como Santo Antônio-Guaçu. As classificações guaçú e mini correspondem a "maior" e "menor", respectivamente.

17 Nessa exploração de 1788, a carta topográfica dos afluentes do Rio Uruguai elaborada pelos demarcadores espanhóis José Varela y Ulloa e Sebastião da Veiga Cabral indicou a discordância entre os dois comissários, que solicitavam um novo tratado entre as cortes ibéricas e registraram o seguinte texto:

(...) não estão conformes os nomes de alguns rios e arroyos que correm pelos terrenos que se reconheceram desde a Barra do Arroyo Chuy até a entrada do rio Pepiriguaçu no Uruguai; por cujo motivo desejando os dois respectivos comissários evitar confusão que disto se pode seguir, quando se tratar nas Cortes de estabelecer definitivamente os limites, acordarão também expressar reciprocamente nos mesmos planos estas diferenças. ${ }^{7}$

18 A impossibilidade de realizar a mensuração in loco ainda no período setecentista deixa em aberto a necessidade de reconhecimento da área limítrofe em momentos posteriores ao Tratado de Madrid, além das incertezas frente às representações cartográficas resultantes desses trabalhos de demarcação efetuados após o acordo de 1750.

Essa dificuldade de produzir um levantamento fidedigno acabou por nutrir dúvidas posteriormente quanto a capacidade de apreensão do real nos trabalhos demarcatórios de advindos do Tratado de 1750 - visto que, conforme indicado acima, algumas partes foram apenas esboçadas a partir de observações auxiliares. Para os Estados americanos, essa condição foi interpretada como uma possibilidade para ambicionar possíveis expansões a partir da construção semântica, cartográfica e discursiva de argumentos que assegurassem as pretensões que buscavam.

Como estratégia para desconstrução dessa assertiva, Rio Branco buscou evidenciar como em representações prévias ao Tratado de Madri já configurava a designação "Pepery" para o rio que o Estado brasileiro sustentava ser a linha limítrofe. Logo, a cabeceira mais próxima também correspondia à nascente daquele que era compreendido como Santo Antônio. As documentações usadas pelo Barão Rio Branco retomam as estratégias usadas pelos lusitanos, a exemplo da carta produzida por D'Anville. A Carte de l'Amérique Méridionale foi encomendada como estratégia lusitana para antever as negociações territoriais advindas do término da Guerra da Sucessão Espanhola, ${ }^{8}$ que foi percebida por Dom Luís Cunha como oportunidade adequada para a elaboração de uma base cartográfica. É desse contexto que, conjuntamente com D'Anville, foi elaborada a referida carta e que, posteriormente, culminou nas fronteiras propostas no Tratado de Madri (Furtado, 2011). O que se buscava era construir uma imagem de América Portuguesa com as fronteiras desejadas pela Coroa Portuguesa, mesmo que ainda não efetivadas. 
21 A partir dessa contextualização, é possível sustentar que a qualificação dos topônimos foi assumida como estratégia geopolítica para afirmação das posses territoriais. Isso porque a atribuição de nomes aos lugares não ocorria desordenadamente, eles estavam inseridos em um modelo cultural que expressava práticas adotadas pelas coroas. Outra característica importante das questões territoriais e diplomáticas do Setecentos é sobre o sistema cultural dos topônimos (Kantor, 2009), influenciado pelas mudanças advindas dos tribunais europeus. A designação dos nomes dos lugares estava atrelada ao conjunto de práticas político-territoriais que visavam assegurar o domínio das posses e, portanto, não se constituiu como algo espontâneo ou não pensado (Kantor, 2009). Nesse sentido, a observação dos elementos que fundamentavam as concepções jurídicas tornou-se um ponto de referência para ajustar as práticas territoriais com o intuito de atribuir consistência entre o real e o "mundo no papel". Consequentemente, a designação dos topônimos foi assumida como estratégia geopolítica para afirmação das posses territoriais.

Para Kantor (2009) os espanhóis eram mais cuidadosos na atribuição dos topônimos, enquanto os lusitanos o fizeram de maneira fortuita. Na interiorização das conquistas houve um amplo emprego dos nomes tupis, o que explica grande parte das nomenclaturas observadas em torno do Prata. O fato de esses topônimos não corresponderem a nenhuma prática comum das coroas, mas sim da onomástica tupi, situava-se como mais um fator que abria possibilidades para manipulações e contestações.

Contudo, essa identificação proposta retomava práticas adotadas ainda pela Coroa de Portugal, uma vez que no Setecentos ocorreu um processo de ressemantização de alguns locais, inclusive dos Campos de Palmas. A partir de 1750, tornou-se oficial nos tribunais europeus a apresentação de documentos cartográficos e descrições textuais para integrar as alegações de posses territoriais, o que originou um sistema cultural toponímico. ${ }^{9}$ Além do emprego da hagiotoponímia ${ }^{10}$ como marca distintiva da expansão lusitana, a imposição de nomes portugueses para áreas já grafadas pelos jesuítas correspondeu a uma estratégia adotada que propendeu efetivar as possessões no ultramar. Assim, “(...) a erradicação da toponímia missionária e a renomeação dos lugares e acidentes geográficos foi parte de uma política mais ampla de afirmação da soberania interna e externa da coroa portuguesa no continente americano" (Kantor, 2009: 47).

Outra mudança toponímica pode ser verificada quando se inserem, nas análises, os primeiros mapas da América do Prata, atentando para a designação atribuída à área objeto deste estudo. A denominação que apareceu nos primeiros mapas confeccionados pelos jesuítas com o nome de "Ibiturunas/Bituruna", sendo posteriormente nomeada nos mapas do Império brasileiro como "Campos de Palmas", o que indica que houve uma ressemantização por meio da qual os lusitanos almejavam condições para fixar o uti possidetis - estratégia que posteriormente foi aproveitada por Barão do Rio Branco, ao propor a alteração do nome da querela da Questão das Missões para Questão de Palmas.

Pode-se inferir que, conscientes da importância da origem dos topônimos e de todo o sistema cultural e político em torno deles, houve a nomeação de referências (seja locais terrestre, fluviais, bosques, etc.) de modo, que a distribuição dos nomes no espaço (representados nas cartografias) criasse coesão com um discurso fronteiriço e territorial, possibilitando endossar os argumentos que justificassem as expansões 
espaciais de cada país. Ou seja, a nomeação das referências levou em consideração as possibilidades de expansão: ou almejando interiorização para o leste, no caso argentino; ou reafirmando posse de terras usurpadas na costa platina, no caso brasileiro.

Além dessa manipulação, a adjetivação mini e guaçú era prática espanhola e não lusitana. Costumeiramente, ressalta-se a possibilidade de extensão para o leste no caso argentino. Todavia, uma análise do conjunto dos topônimos e suas localizações, da localização de algumas riquezas naturais, do momento econômico e tecnológico argentino, permite-nos indicar que muito mais importante que a saída para o leste era a posse das Quedas do Iguaçu (Moraes, 2018).

\section{A terra do ouro verde e da hulha branca: das motivações em torno da Missões/Campos de Palmas}

Os contextos histórico-geográficos do Brasil e da Argentina durante os anos finais da QMP possuem alguns pontos em comum. O principal deles é que ambos estavam em processo de formação territorial, momento no qual a soberania sobre a área em disputa detinha um importante papel para os interesses econômicos. Desse modo, são apresentados de forma sucinta, nos próximos subtítulos, alguns aspectos da formação territorial de cada país, com a finalidade de contextualizar o litígio no projeto políticoeconômico de cada país.

\section{Desenvolvimento econômico, federalização e cartografias: os interesses e estratégias de conquista espacial do Poder Central argentino}

Na segunda divisão internacional do trabalho, Argentina e Brasil estavam inseridos no desenvolvimento de uma economia agroexportadora, com produtos de agricultura tropical e com a extração de minerais, como também era possível encontrar o desenvolvimento de atividades manufatureiras. Estas últimas, embora com participação em menor proporção nos dois países, correspondia ao setor que despertava interesses por frações da classe dominante para que recebesse maiores estímulos. $O$ final do século XIX, era um contexto de modernização da economia em geral, seja da agroexportação, seja da manufatura. Essa conjuntura econômica implicou em uma releitura das fronteiras, visto que a indefinição entre Brasil e Argentina possibilitava incorporar mais recursos naturais ao patrimônio territorial de cada país. Vale ressaltar que a disputa sobre a área fronteiriça foi intensificada no final do século XIX possivelmente motivada também devido à economia de cada país.

A formação territorial que o Estado empreendeu para consolidar as referidas atividades e, por conseguinte, sua inserção na economia mundial, exigiu uma adequação da sua organização institucional para viabilizar essa demanda. Deste modo, é possível perceber que ao mesmo tempo que ocorria a formação territorial (seja em relação aos limites internacionais, seja internamente) também o próprio Estado criava a si próprio como uma instituição. $O$ tipo de Estado adotado por cada país implicou diretamente nas políticas territoriais desenvolvidas nas proximidades da área litigiosa, que, por sua vez, interferiu no desenrolar dos fatos. A Argentina era uma República Federativa, o que atribuía maior autonomia às oligarquias regionais (criando um espaço institucional 
para internalizar na estrutura do Estado, as rivalidades já existentes entre as oligarquias de Buenos Aires e algumas províncias). O Brasil, por sua vez, era um regime monárquico, cujos princípios limitavam o poder de atuação das províncias, visto que atribuiu papel determinando ao poder central para interferir na jurisdição das provinciais imperiais. É oportuno salientar que a integridade territorial sempre foi um elemento importante no simbolismo da política brasileira, não sendo diferente no período imperial. Foi a partir das particularidades político-administrativas de cada Estado, que estes empreenderam medidas que objetivassem conquistar soberania sobre a área litigiosa.

Para a Argentina, é possível identificar, na criação dos Territórios Nacionais (1880), durante a presidência do General Júlio Roca (1880-1886), uma estratégia significativa para garantir a posse em áreas conflituosas ou cobiçadas. A criação desses Territórios submetia as áreas consideradas como estratégicas para o domínio direto do Governo Central, com o intuito de melhor condução dos projetos federais (Souvi, 2010), visto que deixavam de fazer parte da estrutura administrativa das Províncias. A partir da década de 70 do Oitocentos, o governo argentino criou sucessivas leis que organizaram a administração dos "espaços vazios" (Zusman e Minville, s/d: 3). Nestes, era primordial impor outra organização, uma vez que foram antigos territórios dos indígenas ou organizações sociais que não estavam em total sincronia com os objetivos da elite argentina. Para Zusman e Minville (s/d: 2. Tradução livre): "a formação do Estado Nacional argentino foi um processo planejado que implicou uma 'invenção' de um territorio 'legítimo' sobre o qual era possível exercer o dominio". ${ }^{11}$ Integrando um conjunto de medidas políticas, foram criados diversos territórios nacionais em áreas estratégicas, como o Território do Chaco (lei 576, de 18-10-1872), Território Nacional da Patagônia (lei 954, de 11-10-1878), e também o Território Nacional de Misiones em 24-12-1881 (Zusman e Minville, s/d:3).

O Território Nacional de Misiones era composto por seis departamentos: ${ }^{12}$ Posadas, San Martin, Piray, San Xavier, Monteagudo e Iguaçú. Os departamentos de Monteagudo e Iguaçú tinham em sua jurisdição a área litigiosa, abrangendo áreas que correspondem a partes dos atuais estados do Paraná e Santa Catarina, como pode ser visualizado na Figura 2. A federalização foi compreendida como requisição oficial da Argentina acerca da soberania dos Campos de Palmas, tendo no Mapa do Território Nacional de Misiones (MTNM) uma apropriação simbólica, com importante conteúdo e relevância política para o período. ${ }^{13}$ 
Figura 2: Parte do Mapa do Território Nacional de Misiones

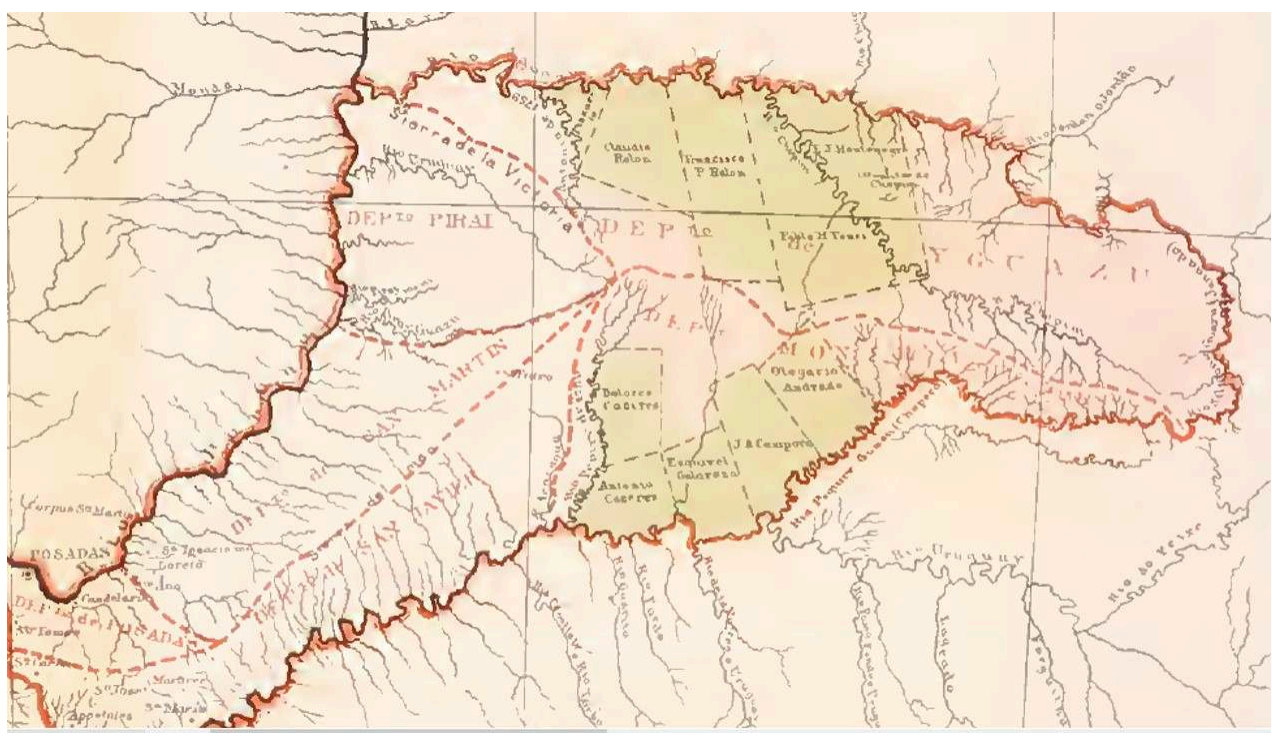

Parte do Mapa do Território Nacional de Misiones. Na parte central do Território, é possível identificar áreas divididas (com coloração distinta do restante do mapa), as quais, possuem o nome de uma pessoa registrado sobre as mesmas

Fonte: Zeballos, 1894

Para Souvi (2010), a federalização das Missões, desanexando-a de Corrientes e subordinando-a diretamente ao Governo de Buenos Aires, está relacionada à questão litigiosa com o Brasil. A referida medida possibilitava fazer efetivos seus direitos sobre essas terras próximas à área litigiosa, colocando-a sob o controle federal da Argentina. Essa medida foi amplamente debatida na imprensa nacional argentina e entre os políticos, dado que naquele contexto de formação territorial, a federalização estava relacionada não apenas a questão litigiosa, mas com a relação do poder central sobre as oligarquias das províncias. Pertencente a Corrientes desde 1832, o Presidente Roca, por meio do Projeto de Lei 1.149, de 20 de dezembro de 1881, artigo $1^{\circ}$, determinou que "declara-se nacional o território de Misiones cujo limite ao oeste ficará fixado pelo curso principal do Rio Aguapey, desde sua desembocadura no rio Uruguai até o Paralelo $28^{\circ}$ de latitude sul e de ali (seguirá) pela linha meridiana até o Rio Paraná" ${ }^{14}$ subordinando esta área ao poder nacional. Em virtude disto, houve protesto pelos fazendeiros de Corrientes em relação a medida tomada pelo Poder Central, visto que aqueles possuíam terras nas Missões (Souvi, 2010: 05). Tal fato acentuou a animosidade já existente entre Corrientes e a elite portenha, em virtude das disputas políticas internas durante o processo de formação territorial e estatal da Argentina (Bethel, 2001).

A federalização de Misiones foi também incentivada em razão da implantação da Colônia Militar do Alto Uruguai na Província de São Pedro do Rio Grande do Sul (Brasil), no ano de 1879, em área que hoje corresponde ao atual município de Três Passos. Essa Colônia tinha como função "guardar as terras do Noroeste e observar a movimentação das picadas", funcionando como uma espécie de posto avançado do Estado nas proximidades de áreas cobiçadas e litigiosas. Assim, o Território Nacional das Missões foi construído em meio a interesses internacionais e internos, pois além da indefinição fronteiriça com o Brasil, desencadeava divergências e disputas internas na própria Argentina, entre o Poder Central e as oligarquias de Corrientes. Em certa medida, 
visualizamos aproximações e dissidências com a formação territorial brasileira, já que a área litigiosa também foi espaço de disputas internas entre os estados do Paraná e Santa Catarina. Porém, a política territorial empregada pelo Império do Brasil tratou de conciliar os interesses do Paraná com o poder central, ao optar por não desmembrar a área litigiosa para governar, adicionado ao fato que preferiu interiorizar sua presença através da implantação das colônias militares e com isso, conservou a administração da área litigiosa com oligarquias regionais (sobretudo paranaense). Somente após a resolução do litígio internacional é que a disputa interna adquiriu maior vigor, mas ainda entre as próprias oligarquias estaduais (catarinense e paranaense). ${ }^{15}$

Em 1879, ao tomar conhecimento da provável federalização das Missões, a Província de Corrientes iniciou a comercialização das terras fiscais mais ricas e férteis a grandes latifundiários, a preços baixíssimos. Um total de 750 léguas foram comercializadas com 38 compradores, convertendo-as em latifúndios improdutivos, pois foram relegadas para exploração futura, restando poucas terras públicas que, devido à proximidade com as manchas de ervais, não poderiam ser comercializadas. ${ }^{16}$ No somatório, isso representava um impasse ao processo civilizador missioneiro, pois acabou por criar mais um problema para uma área que já era litigiosa, reduzindo os efeitos das medidas adotadas pelo poder central. A urgência para conquistar a vanguarda diante da federalização resultou em um processo de comercialização marcado por erros na mensuração da terra, problemas com os títulos emitidos e outras irregularidades, o que permitiu a recuperação de grande parte dessas áreas para a condição de terras fiscais.

Deve ser considerado, ainda, que Buenos Aires impôs sobre as regiões ervateiras legislação própria, com o intuito de evitar a devastação dos ervais, e proibiu a colonização das terras próximas a eles - o que contribuiu para a perda de Missões (Aranha, 2014: 90). A contribuição decorre do fato que um dos critérios empregados para validar as ações de um Estado sobre uma determinada área era o povoamento da mesma, dado que esta política era interpretada também como ação para "civilizar" as áreas interioranas. $\mathrm{O}$ uso deste critério nas situações litigiosas não era algo inédito ou desconhecido. Conforme mencionamos nos parágrafos anteriores, a partir do século XVIII os dados empíricos (seja ocupação, seja topônimos) foram cada vez mais usados para designar a soberania sobre uma área. E é válido ressaltar que um dos critérios usados por Grover Cleveland, presidente estadunidense e árbitro do litígio, foi o uti possidetis.

36 A comercialização de terras realizada pela Província de Corrientes implicou em dificuldades internas, em questões políticas e no desenvolvimento de políticas territoriais relacionadas à integração missioneira, bem como frente ao litígio internacional ali existente. Contudo, o início da comercialização de terras orquestrada pelas oligarquias correntinas não significou a impossibilidade da exploração por empresas particulares de mate, madeira e navegação. Dessas corporações, podem ser mencionadas "Cia Argentina de Navegacion", "Cia Mercantil y Transporte Domingos Barthe”, Nunes Gibaya e Juan B. Molla (Freitag, 2007; Alcaráz, 2013).

Conforme destacado anteriormente, a atividade voltada para o mercado externo, desenvolvida pelos grandes proprietários, era majoritariamente a pecuária e o plantio de cereais. Então, cabe aqui a interrogativa sobre por quais razões Misiones era visto como importante espaço estratégico e como se conectava com a ascensão econômica dos ganaderos da região dos Pampas. ${ }^{17}$ A Argentina foi inserida na Divisão Internacional do Trabalho no século XIX, vinculada ao modelo agroexportador, sobretudo, através 
das atividades de carnes e cereais, enquanto as demais províncias que tinham suas economias "isoladas" foram inseridas no mercado interno: Tucuman e Jujuy na produção de açúcar; Chaco e Formosa, algodão; vinho em Cuyo; e as Misiones, responsável pelo abastecimento de mate (Aranha, 2014; Souvi, 2010). Desse modo, o desenvolvimento dessa atividade com fins de atingir independência comercial era um objetivo evidente, o que reduziria os gastos com a importação do mate brasileiro e fortaleceria ainda mais a economia interna. Com uma importância ainda maior, podemos destacar as Quedas do Iguaçu devido à exploração energética para o desenvolvimento industrial.

Frente a esse contexto, tornava-se necessário mapear, identificar, descrever e conhecer uma área que, de certa forma, ainda permanecia ignota. O conhecimento geográfico torna-se importante ferramenta para a valorização simbólico-nacional dessa área. A combinação entre política e ciência, tão comum nos processos de formação territorial, adquiria contornos e ênfases "do processo civilizador" e conteúdo "missioneiro". A disseminação de relatórios de viagens patrocinadas ocorria, sobretudo, por meio do Instituto Geográfico Argentino, que atuava em consonância com as ideologias assumidas pelo Governo (Aranha, 2014). A partir desses discursos foi possível identificar que, em torno dessa disputa, estavam interesses vinculados ao potencial energético das Quedas de Iguaçu.

O povoamento era uma temática pertinente no pensamento político, social e territorial do período, frequentemente associado à capacidade do Estado de ocupar efetivamente seu território e, por conseguinte, dar condições para o crescimento de sua sociedade capitalista. Como pano de fundo do processo civilizador no século XIX, havia um componente territorial sob uma ótica interna e externa. O Estado brasileiro se fazia presente na fronteira de forma efetiva, ao contrário do país vizinho. A presença do Estado argentino era reclamada pelos viajantes oficiais (como Ambroseti, Basaldúa, Lista), que interpretavam de extrema importância a presença não apenas na porção oeste de Misiones, mas também no leste, na proximidade da fronteira com o Brasil.

Dos viajantes argentinos, é relevante apontar algumas colocações, as quais evidenciam as leituras sociais e geográficas do período, por exemplo quando Ambroseti (1893: 133 apud Aranha, 2014: 81) ultrapassou a fronteira internacional e percorreu outras vilas brasileiras ${ }^{18}$ bem como a Colônia Militar do Alto Uruguai. 0 viajante apontava o cenário encontrado como indício de que o Brasil estava à frente do processo civilizador, de modo que se fazia presente de forma efetiva nas extremidades de seu território. A ocupação brasileira, mais efetiva e muito próxima à área litigiosa, possuía uma carga simbólica considerável em um contexto em que o povoamento servia como argumentação jurídica nas conquistas territoriais - o que de fato foi usado pelo plenipotenciário brasileiro no arbitramento de 1895.

\section{A interiorização do Império e a defesa das fronteiras: a importância das Colônias Militares para o expansionismo imperial brasileiro na bacia Platina}

41 A questão da fronteira oeste na bacia Platina era fundamental para a manutenção do território das oligarquias brasileiras, bem como para o prestígio geopolítico que a mesma possuía. Diferentemente das questões territoriais anteriores, como a das 
Guianas, a disputa era com um país latino-americano e não mais com um país europeu. Isso implicava em equilíbrio de poder e influência na bacia Platina.

Enquanto vigorou a América portuguesa, os domínios territoriais lusitanos foram significativamente ampliados para o oeste. Durante o Brasil Império, a manutenção do território herdado da Coroa portuguesa foi um dos principais objetivos que orientaram as políticas territoriais. Assim, além das negociações com as oligarquias provinciais para manutenção da integridade territorial, também foram estabelecidas políticas que visavam à interiorização do poder e do "olho do Imperador". O governo imperial brasileiro já vinha desenvolvendo, como estratégia política, jurídica e territorial, a criação concreta de elementos que assegurassem o emprego do uti possidetis, ${ }^{19}$ tais como a criação de cidades e vilas (Delson, 1997) e a criação de colônias militares em diferentes partes do território (Brugmann, 2013).

Em relação à nossa área de estudo, podemos indicar dois eventos condicionantes a partir dos quais as demais ações de domínio e conquista foram constituídas em um somatório, e foram relevantes no desfecho do litígio. Em um primeiro momento, em 1839-40, ocorreu a conquista da área que era identificada como Ibituruna, nomeando-a como Campos de Palmas. A interiorização e a conquista da área vinham com claríssimos interesses geoestratégicos - expressados pela conquista dos campos, bem como pelas expedições para abertura de vias (Moraes, 2018). A partir da criação da Vila de Palmas, algumas expedições exploratórias eram realizadas e possibilitavam a observação da movimentação que transcorria na fronteira, seja em relação à atividade tropeira, ervateira ou de pessoas.

Além dos interesses expansionistas sobre as repúblicas latino-americanas, também eram fator de preocupação nesse período as movimentações e ações da Guerra dos Farrapos, que havia começado em 1835. O movimento visava a separação da Província de São Pedro do Rio Grande do Sul. No ano de 1839 alcançou Laguna (SC) e ali foi proclamada a República Juliana. Posteriormente, espraiou-se também para o planalto catarinense, na Vila de Lages, e em Curitibanos, ${ }^{20}$ ambos mais próximos aos Campos de Palmas quando se compara ao litoral. O movimento de ideologia liberal, ${ }^{21}$ também inspirado na guerra da Independência do Uruguai, estabeleceu conexões com esta Nova República do Rio da Prata, além de relações com Corrientes e Santa Fé - ambas localizadas na Argentina. Isso gerou um quadro de instabilidade na região meridional do Império brasileiro, impulsionando práticas espaciais que visaram ampliar a presença imperial para controlar e ocupar as áreas interioranas, bem como combater o movimento farroupilha. A criação da Vila de Palmas em tal contexto conseguia introduzir um posto avançado de controle e vigia que poderia facilitar o deslocamento de tropas e materiais tanto para oeste, em direção à Argentina, quanto para leste, aproximando-se de Curitibanos e Lages.

45 A construção de vias para a direção oeste configurava-se como estratégica, primeiramente pela obtenção de meios de apropriar-se com mais efetividade de uma área que permanecia como desconhecida pela maioria. Em segundo lugar, por sua proximidade com áreas que estavam sob controle e influência das oligarquias provinciais argentinas - estas últimas mantinham relações com os farrapos.

46 Além da criação da Vila de Palmas, posteriormente também foi criado um povoado localizado a oeste desta, o qual foi nominado como Campos Erê. Ali, também se desenvolveu povoamento com concessão de títulos de terras e atividade agropastoril como instrumento de conquista e controle espacial. 
47 Em um segundo momento houve a criação das quatro colônias militares próximas à área litigiosa, com o intuito de intensificar o povoamento e atribuir consistência às argumentações sustentadas. Ao contrário da criação das vilas supramencionadas, a instalação das colônias militares ocorreu somente ao final do século XIX, fortemente impulsionada pelas políticas territoriais na Argentina.

48 Nesse contexto, as colônias militares podem ser compreendidas como mais uma estratégia de conquista territorial e defesa de fronteiras empregada no regime imperial. A implantação de unidades administrativas para povoamento, fossem elas de natureza militar ou civil, foi uma prática recorrente na conquista da América portuguesa, bem como na dilatação das fronteiras brasileiras. Essas criações visavam consolidar a posse de áreas, que eram alvo de constantes disputas.

49 A prática de criar unidades administrativas que interiorizassem a presença do Estado também foi mantida durante o regime monárquico, porém, além daquelas de natureza civil (vilas, cidades etc.), passou a implantar as colônias militares. Vale salientar que a adoção desta estratégia territorial de colonização militar só foi efetivamente desenvolvida após ser conquistada a estabilidade política com a redução das revoltas regionais e com a conquista da centralização do poder. Foi a partir da estabilidade interna, que se conformou um contexto adequado para o governo deliberar sobre questões territoriais e econômicas, nas quais as colônias militares eram inseridas como estratégias para atender a ambas as demandas (econômicas e territoriais).

50 A natureza geopolítica de colonização militar, está expressa em alguns preceitos jurídicos, tais como: em 1850, com a Lei Imperial no 555, foi aprovado que o orçamento do governo central previa o estabelecimento de presídios e colônias militares, atentando à sua mais adequada organização, indicando que deveriam ser implantados dentro de uma “zona de dez léguas contígua aos limites do Império com Países estrangeiros e em terras devolutas". ${ }^{22}$ Essas instituições, tiveram a finalidade predominante de catequizar os indígenas e servir como baluarte para o povoamento populacional, mediante a concessão de títulos de terras a colonos, militares ou não. Também tinham como objetivo dar apoio à circulação de mercadorias e pessoas por meio da navegação fluvial ou das tropas. Por fim, tornar exequível a exploração dos territórios, que ainda permaneciam sem exploração integrada ao sistema capitalista.

51 A criação de colônias militares era compreendida como uma medida mais adequada e cabível às condições orçamentárias do Império do que a criação de ferrovias - que também era um meio para "dirigir pessoas para os desertos". ${ }^{23}$ Ao todo, foram criadas 29 colônias, com objetivos em comum para todas e alguns mais específicos. Para as colônias implantadas nas proximidades e nos Campos de Palmas, é muito evidente que, dentre suas funções, estava o exercício de poder, motivado, seja a nível internacional ou doméstico. É relevante apontar que a federalização do Território de Misiones pelo Governo Central argentino e a divulgação do mapa do respectivo território em 1881 foram a pedra de toque para que o governo brasileiro efetivamente implantasse duas colônias militares (do Chapecó e do Chopim) próximas à área litigiosa no ano seguinte (1882). As colônias tinham como objetivos defender a fronteira, realizar concessões de terras, desenvolver atividades econômicas, proteger os habitantes dos Campos de Palmas, Guarapuava, Erê e Xagu contra a incursão dos índios e catequizar os indígenas.

52 As colônias militares eram identificadas como instrumentos que poderiam promover o desenvolvimento de atividades econômicas, bem como abrir novas frentes de colonização. É evidente que a prática da implantação das colônias militares não 
correspondeu a uma ação isolada no território meridional, mas parte de uma política de exercício de poder sobre as posses mais interioranas, próximas a limites não estabelecidos, cujas fronteiras eram demarcadas por porosidade e transitoriedade de pessoas e mercadorias. O comércio de mate, embora conferisse possibilidade de comercialização dos produtos confeccionados nas vilas e, posteriormente, nas próprias Colônias Militares pelos colonos-militar, ${ }^{24}$ foi compreendido majoritariamente como atividade suspeita, visto que a direção do comércio para oeste não era uma rota sob controle do Estado brasileiro.

A implantação de uma estrutura administrativa estável conferia maior presença e controle da área fronteiriça, a partir da construção de uma base material e organizacional que ampliava a presença e influência do Estado imperial para além da área da Colônia Militar através de trabalhos de exploração de terrenos adjacentes, produção de material cartográfico e relatórios sobre as expedições. Estes últimos também com informações sobre as áreas e trajetos percorridos.

Isso implicava, também, na instalação de uma estrutura que conferisse ao Império a vigilância da área e elevação do controle dos fluxos. Nessas circunstâncias, é possível considerar que a sede da Colônia Militar do Chapecó representava a consolidação de uma nodosidade (Raffestin, 1993) da tessitura do Estado Imperial que mantinha sob sua influência uma área além dos limites da sede.

O conceito de nodosidade advindo da ideia de uma rede/tessitura, em que os pontos, feitos pelo entrecruzamento de duas ou mais linhas, correspondem aos "nós" que consolidam essa rede, ${ }^{25}$ além de contemplar a propriedade de ponto implantado e envolvido em uma tessitura de poder, também permite designar as ações e práticas de comandar, controlar uma extensão, uma área periférica a nodosidade. Ou seja, a potencialidade de ação e influência de uma "nodosidade" vai além de suas delimitações físicas (no nosso caso, a sede da Colônia Militar) e incorpora as áreas vizinhas, periféricas, sob controle de alguma instituição política (Estado da Argentina) ou ainda de soberania imprecisa. Essa propriedade de influência ao entorno, consubstanciando uma área sob regência de um dado poder, não vem da ideia de nó, mas da natureza do aparato administrativo implantado: o controle geoestratégico da fronteira se consolidava para além das delimitações da sede da colônia, no controle e vigília do entorno. Tratava-se, portanto, da consolidação de um campo operatório de ações militares e não militares, que em conjunto pudessem conferir uma diferenciação funcional ou impor um ordenamento/controle dos fluxos. O campo operatório de ações é consolidado em virtude que a natureza da tessitura a qual pertence a nodosidade em questão (Colônia Militar) permite que os agentes paradigmáticos ${ }^{26}$ possam acender a categoria de sintagmático, construindo uma área de influência na qual conseguem exercer influências e desenvolver projetos de ações, tornando o entorno, uma área periférica devido ao posicionamento das ações dos agentes.

o cumprimento da defesa de fronteira foi um objetivo traçado em conjunto com a necessidade de executar uma organização social, política e geográfica nos moldes de um novo tempo orquestrado pelos conceitos de civilização e progresso. ${ }^{27}$ Sem ignorar as especificidades dessas organizações políticas ibero-americanas e do lugar que as mesmas dispunham na estruturação da economia mundial, é possível identificar uma busca recorrente a alguns conceitos que serviam como modulares para o desafio de se organizar política, social e geograficamente ao longo de toda segunda metade do Oitocentos, bem como início do século XX. A formação do estado territorial não deixava 
passar despercebido quais representações sociopolíticas do período eram consideradas como importantes balizas para identificar Estados que efetivamente conseguiam governar seu patrimônio territorial (ou aquele que julgavam sê-lo). Em outros termos, era a manifestação de qual Estado possuía mais capacidade de articular essa área com a própria expansão da economia que se alastrava pelo mundo por meio das ferrovias, telégrafos e do povoamento. ${ }^{28}$ Essas representações foram incorporadas no discurso do Rio Branco como demonstrações da capacidade brasileira de colaborar com a missão de levar a civilização às áreas ainda ignotas. Essa associação entre as políticas territoriais do Império do Brasil e as representações supramencionadas não passaram despercebidas pelos viajantes argentinos. ${ }^{29}$

Se no período setecentista existia um ajuste entre as práticas toponímicas com os tribunais internacionais para decisão de posses territoriais, em finais do século XIX e início do século XX esse ajuste vai desembocar sobre os conceitos de progresso e civilização. Nessa perspectiva, a implantação de povoados com estrutura que os interligasse à alguma entidade administrativa era usado como importante demarcador de capacidade de produção territorial nos moldes dos ideários modernos. Ainda dentro dessa concepção que investia classificações e hierarquizações para as diferentes formas de organização espacial, conservando um viés dicotômico como sertão-litoral (Brasil) ou campo-cidade (Argentina), também era caracterizadora do progresso a presença de elementos tecnológicos representantes desse novo tempo histórico: como o telégrafo e ferrovia. Se a ferrovia ainda não havia chegado até as colônias militares, além de algumas estradas já existentes, havia o trabalho contínuo de realizar incursões com a finalidade de construir redes geográficas que pudessem produzir conexões com outras regiões - algumas delas, contempladas com ferrovias.

Em relação ao objetivo econômico, acreditava-se que poderia estimular o povoamento no interior expandindo o comércio, a indústria e a comunicação nas áreas interioranas. Durante a modernização do território brasileiro para concretizar os interesses dos grupos ligados ao capital agromercantil, a região meridional brasileira foi identificada como área apta ao desenvolvimento de produção de gêneros agropecuários para complementar a economia doméstica.

\section{"O Peperi vale mais que o Nicarágua" ou "as Cataratas do Iguaçu valem mais que as Quedas de Niágara"? Os interesses internacionais nas disputas territoriais da Questão das Missões/ Palmas}

Ao longo da pesquisa de doutoramento foi lançada frequentemente a interrogativa dos interesses por detrás da QMP. Não é novidade que as disputas territoriais são tecidas no bojo de interesses econômicos. Em nosso objeto de estudo, são exemplificadas, sobretudo, pela atividade ervateira, madeireira e também por questões relativas ao deslocamento e circulação de mercadorias, seja para atingir o interior do Brasil central ou o Atlântico - importância que o Barão do Rio Branco expressou no excerto que compõe o título desse item: "O Peperi vale mais que o Nicarágua". ${ }^{30} \mathrm{~A}$ referência que o plenipotenciário indica é claramente a navegação, apresentada como fundamento dos direitos soberanos brasileiros sobre esse território. 0 domínio da navegação, bem como seu melhor aproveitamento e sua exploração, eram condições ansiadas em um período de intensas inovações tecnológicas, as quais poderiam implicar na agilização da 
circulação de mercadorias, pessoas e informações. Isso resultava em maior dinamismo para as atividades econômicas e em maior integração com os demais centros econômicos distribuídos pelo território. O escoamento pelo Rio Jangada ou mesmo Chopim, que desemboca no Santo Antônio, permitia acesso tanto à porção central do Brasil quanto à saída para o Prata, sem necessariamente ter que chegar até o litoral. Esse raciocínio pode ser aplicado também à navegação no Rio Uruguai, que transportaria mercadorias e pessoas do vale que o entorna (já cobiçado como área para povoamento) para atingir o estuário Platino.

O levantamento técnico para averiguar as condições de navegabilidade do Rio Uruguai (com o intuito de melhorá-las) foi efetuada pela Colônia Militar do Alto Uruguai (Xavier, 2013). Da mesma forma, as condições de deslocamento fluvial foram observadas ao longo de todo os trabalhos demarcatórios, a exemplo do que consta no Relatório da Segunda Partida ao afirmar que “(...) a corredeira dos Macacos Brancos de perigosa navegação quando o rio está cheio a qual termina pouco acima da estação 12, dois insignificantes arroios entre as estações 7 e 9" (Argentina/Brasil, 1903: 11). Os recursos fluviais mencionados como limítrofes pelos argentinos se constituíam para os brasileiros como alternativas importantes para os produtos de áreas interioranas, como Campos de Palmas, Mato Grosso, noroeste rio-grandense, entre outros.

61 As vias terrestres que interligavam os Campos de Palmas a outras regiões do Brasil, fosse em direção setentrional, meridional ou oriental, eram escassas, de condições de deslocamento ínfimas, de modo que não conseguiam reduzir as "barreiras geográficas" que demarcavam a área fronteiriça. Nessas condições, o deslocamento fluvial permitia agregar alguma velocidade e se constituía quase como a melhor opção desse território em questões de fluidez.

62 Embora todos esses elementos da navegação fossem importantíssimos, expressos na correspondência de Barão do Rio Branco a Salvador de Mendonça, não introduziam novos elementos que pudessem dar pistas a outras possíveis atividades ou explorações vislumbradas que justificassem a importância com que a Questão foi tratada no período. A resposta advém dos registros das viagens efetuadas pelos viajantes financiados pelo Governo argentino. É do viajante Balsadúa a confirmação de que, além de terras, mate e madeira, também o potencial energético nutria as disputas em torno do espaço fronteiriço. Basaldúa, efetuando comparação com as cataratas yankee, destaca que a catarata situada na bacia Platina era mais opulenta e, embora não apresentasse os dados de medição, cogitava que sua força motriz era dez vezes superior as da Niágara, medidas por Carl Wihlmen Siemens. Em paralelo, a referida afirmação trazia iconografias que demonstravam a referida opulência:

Assim como a beleza natural das cataratas do U-guazú, com seu esplendoroso marcado de flores, de cipós e de orquídeas, abaixo de um céu esplendido, é imensamente superior a beleza da Niagara, enquadrada na sombra da vegetação, assim também a força das mil cascatas em que se subdivide o U-guazú é pelo menos dez vezes maior que sua rival norte-americana, que o sábio Siemens tem estimado em 16.800.000 - dezesseis milhões e oitocentos mil - cavalos-vapor. A magnifica paisagem detém, pois, tesouro inesgotável de forças latentes que em dia não distante transformação os engenheiros argentinos em mananciales de civilização, levando através de uma rede de ruas a todos os âmbitos da República correntes de luz, de calor e de força elétrica recolhidas nas turbinas ao pé das cascatas. (Basaldúa, 1901: 166 apud Aranha, 2014: 148) ${ }^{31}$ 
63 Cataratas do Niagará, e igualmente foram temas da Exposição Cientifica de Bufallo em
1901, nos EUA (Aranha, 2014: 16). Junto com o mate, são elementos de valorização do território de misioneiro, usado pelos argentinos tanto para atrair investidores como para afirmar sua posse sobre o território.

Para Lisboa Nobre (2012), a Primeira República brasileira pode ser caracterizada por significativo esforço na modernização do setor elétrico no país, por meio de políticas que visavam aproveitar os recursos hidricos para produção da energia. Todavia, ressalta Magalhães (2007) que o setor mais serviu para a busca de lucratividade do que verdadeiramente como o propulsor do esperado "progresso", já que esse exige políticas sociais incompatíveis com o pensamento liberal-conservador que comandava a política brasileira de então.

pela demanda da indústria crescente, durante os primeiros anos do século $\mathrm{XX}$, inúmeras outras hidroelétricas foram criadas na região Sudeste ${ }^{32}$ para aproveitar o potencial as cachoeiras e encostas da Serra do Mar. Tornou-se rara a cidade, ou mesmo a fazenda, que não dispunha de suas própria hidroelétricas para o desenvolvimento da indústria (Lisboa Nobre, 2012). Sob as torres de transmissão e baragens construídas para controlar a vazão hidríca, o espaço era reconstruído imprimindo as feições de uma época movida pela esperança do progresso, mas principalmente, definida e composta por interesses mercantis. O processo de urbanização e desevolvimento industrial, especialmente no Sudeste do Brasil, exigia investimentos na busca de fontes energéticas para essas atividades. A introdução dessa energia durante a República Velha e suas aplicações domésticas, comerciais e industriais passou a ser vista como oportunidades para investimentos e obtenção de lucros, o que fomentou a formação de companhias para aquisição das concessões nesse setor. Assim, formavam-se importantes companhias que funcionavam como monopólios, a exemplo da Light and Power. Se no período anterior ao Tratado de Palmas o Estado não havia estatizado o setor de energia, ${ }^{33}$ haveria ao menos de buscar mantê-lo sob sua jurisdição os recursos que instigassem o investimento de capitais estrangeiros e desenvolvimento de atividades lucrativas - como foi em torno das Quedas do Iguaçu, consistindo em uma prática conciliatória entre os interesses industrializantes e simplesmente comerciais (Magalhães, 2007).

66 Embora raramente sejam mencionadas as quedas e os saltos durante o litígio com a Argentina, em outras documentações posteriores a importância desses recursos naturais começa a tornar-se mais visível. A exemplo, observa-se no Mappa Geral do Estado do Paraná, confeccionado por Romário Martins ${ }^{34}$ em 1919, que traz em escala menor do que aquela usada para representar o Estado, a representação das Quedas do Iguaçú, o que permite dar destaque às suas configurações geográficas, informando “Missões - Território da República Argentina", do lado ocidental das Quedas, bem como informa Estado do Paraná e não Brasil para as posses brasileiras. Essa gradativa inserção e exibição das Quedas permitiu efetuar uma valorização simbólica circunscrita aos limites brasileiros e também paranaense (Freitag, 2007). Do mesmo modo, nas documentações produzidas durante o reconhecimento in loco da fronteira internacional, os registros para as Quedas do Iguaçú são significativos. 


\section{Considerações finais}

67 É possível afirmar que a compreensão sobre a QMP, além de considerar os elementos internacionais entre os dois países, é fundamental para se entender a conjuntura interna de cada país, exemplificada pelos conflitos entre poder central e oligarquias regionais e pela relação com o desenvolvimento econômico - que pressionam uma releitura das delimitações espaciais. As políticas territoriais empregadas indicam a construção de um arsenal de estratégias, que desvelam a minuciosidade pela qual se repartem espaços e neles traçam-se os limites. A importância dos meios e das estratégias em que são tecidas as fronteiras e os limites, sobretudo para as questões de mapeamento, apropriação espacial e reconhecimento in loco, é central para apreendermos a riqueza geográfica presente neste evento. $\mathrm{Na}$ pesquisa de doutoramento (Moraes, 2018), a QMP correspondia a um importante capítulo para entendimento do objeto em estudo (formação territorial de Santa Catarina, especificamente incorporação do fundo territorial oeste catarinense), e ficou evidente a riqueza que este litígio representa para estudos acerca da construção fronteiriça, visto que agrega diferentes práticas territoriais. A constatação dessa riqueza de elementos geográficos ainda não aprofundados serviu de estímulo para a construção de uma investigação, a qual, ainda em curso, estuda o desenvolvimento de uma geopolítica toponímica ao longo de todo o litígio, seja durante o período iberoamericano ou apenas durante o latinoamericano.

\section{BIBLIOGRAFIA}

Alcaráz, Alberto Daniel (2013). La gestacion de una elite local durante la explotacion yerbateramaderera en el Alto Paraná (1870-1920) - Domingos Barthe um representante paradigmático. Dissertação (Mestrado em Antropologia Social). Faculdade de Antropologia Social, Universidad Nacional de Missiones, Posadas, Argentina.

Aranha, Bruno Pereira de Lima (2014). De Buenos Aires a Misiones: civilização e barbárie nos relatos de viagens realizadas à terra do mate (1882-1898). 208 f. Dissertação (Mestrado em Integração da América Latina). Programa de Pós-Graduação de Integração da América Latina. Universidade de São Paulo, São Paulo.

Bethel, Leslie; Cescato, Maria Clara (2001). História da América Latina. 2. ed. São Paulo: EdUSP. Brüggmann, Adelson André (2013). A sentinela isolada. O cotidiano da colônia militar de Santa Thereza (184-1883). 313 f. Dissertação (Mestrado em História) - Programa de Pós-Graduação em História, Universidade Federal de Santa Catarina, Florianópolis, Santa Catarina.

Freitag, Liliane (2007). Extremo-Oeste paranaense: história territorial, região, identidade e (re)ocupação. 209 f. Tese (Doutorado em História). Faculdade de História, Direito e Serviço Social, Universidade Estadual Júlio de Mesquita Filho, Franca, São Paulo. 
Furtado, Júnia Ferreira (2011). “Guerra, diplomacia e mapas: a Guerra da Sucessão Espanhola, o Tratado de Utrecht e a América portuguesa na cartografia de D’Anville”. Topoi, v. 12, n. 23, pp. 66-83.

Cortesão, Jaime (2001). O Tratado de Madrid. Brasília: Senado Federal.

Golin, Tau (2011). “Cartografia da Guerra Guaranítica”. Anais do Primeiro Simpósio Brasileiro de Cartografia Histórica. Paraty, 11 a 14 de maio de 2011.

Hobsbawm, Eric (1996). A era do capital: 1848-1875. 5. ed. Rio de Janeiro: Paz e Terra.

Kantor, Iris (2009). “Cartografia e diplomacia: usos geopolíticos da informação toponímica (1750-1850)". Anais do Museu Paulista, São Paulo, v. 17, n. 2, pp. 39-61.

Lisboa Nobre, Paulo José (2012). "Eletricidade, engenharia e defesa ambiental: mudança de rumo no desenvolvimento brasileiro (1900-1934)”. Anais do Simpósio Internacional de Globalizacion, innovación y construcción de redes técnicas urbanas in America y Europa, Universidad de Barcelona, 23-26 janeiro de 2012.

Lois, Carla Mariana (1999). “La invención del desierto chaqueño. Una aproximación a las formas de apropriación simbólica de los territórios del chaco em los tempos de formación y consolidación del Estado Nación Argentino". Scripta Nova, Barcelona, v. 38.

Magalhães, Gildo (2007). “Energia, industrialização e a ideologia do progresso”. Revista Projeto História, São Paulo, v. 34, pp. 27-47.

Moraes, Cristina de (2018). Uma velha moldura habitada por silêncios, um fundo territorial e seis verbos para integrar: a formação territorial do Oeste catarinense (1880-1940). $368 \mathrm{f}$. Tese (Doutorado em Geografia) - Programa de Pós-Graduação em Geografia, Universidade Estadual Paulista, Rio Claro, São Paulo.

Moraes, Cristina de (2017). “O mapa do Território Nacional de Misiones (1881) na conjuntura da disputa territorial entre Argentina e Brasil”. Revista Confins, n. 30.

Raffestin, Claude (1993). Por uma geografia do poder. São Paulo: Ed. Ática.

Souvi, Susana (2010). “La federalización de Misiones”. In: Dossier. Reflexiones en torno a los estudios sobre Territorios Nacionales. Buenos Aires, Argentina.

Zusman, Perla; Minvielle, Sandra (s/d). Sociedades Geográficas y delimitación del território em la construción del Estado-Nación argentino. Disponível em: <http://repositoriorecursosdownload.educ.ar/repositorio/Download/file?file_id=05573c0d-7a0b-11e1-821e-ed15e3c494af>. Xavier, Mario (2016). O Coronel Freitas e a Colônia Militar do Chapecó. Florianópolis: Insular.

\section{ANEXOS}

\section{Documentos}

Cortesão, Jaime. Ofício (extrato) sobre a demarcação dos limites dos domínios espanhóis e portugueses na América, em conformidade com o Tratado de $1^{\circ}$ de outubro de 1777, designando-se os acidentes geográficos a servirem de marcos para $1^{\mathrm{a}}, 2^{\mathrm{a}}$ e $3^{\mathrm{a}}$ divisões, mencionando os respectivos artigos daquele Tratado. Projeto Resgate Barão do Rio Branco - Colônia do Sacramento e Rio da Prata (1618-1826), AHU_ACL_CU_059, Cx. 3, D.207. Acesso: 23/08/2016. 
Rio Branco (2002). José Maria da Silva Paranhos, Barão do Rio Branco. Questão de Limites - República Argentina. Brasília: Fundação Alexandre de Gusmão.

Zeballos, Estanislao (1984). Alegato de la República Argentina sobre la cuestión de limites com el Brasil em el Territorio de Misiones. Washington. Fundação Biblioteca Nacional do Brasil; Setor de Obras Raras. Rio de Janeiro, RJ.

Legislação

Brasil, Decreto n.ำ 1.318, de 30 de janeiro de 1854 .

\section{NOTAS}

1. Tese intitulada: "Uma velha moldura habitada de silêncios, um fundo territorial e seis verbos para integrar: a formação territorial do Oeste catarinense (1880-1940)". Pesquisa financiada pela CAPES/CNPq.

2. No original: El Império del Brasil há cambiado ultimamente estes nombres oficiales del siglo XVIII, por los nombres del Yangada y Chapecó, como he dicho: pero el Arbitro notará que em ningun documento del siglo XVI, XVII y XVIII, se menciona dichos nombre, arbitrariamente introducidos em la discusión (Zeballos, 1894: 5).

3. Corresponde a um princípio de direito internacional que designa que a terra pertence a quem de fato a ocupa. Referido princípio possibilitava que áreas conquistadas através de expansionismo fossem juridicamente incorporadas ao patrimônio de determinados estados, que como consequência tornava inválidas as posses por partilhas jurídicas.

4. Isso pode ser verificado em Kantor (2009: 40), quando a autora afirma que a "após a Paz de Westfália (1648) - que pôs fim a Guerra dos Trinta Anos e garantiu a Independência das Províncias Unidas -, as reivindicações de posse de novas regiões passaram cada vez mais a exigir a apresentação de descrições geográficas e documentação cartográfica".

5. Ofício (extrato) sobre a demarcação dos limites dos domínios espanhóis e portugueses na América, em conformidade com o Tratado de $1^{\circ}$ de outubro de 1777, designando-se os acidentes geográficos a servirem de marcos para $1^{\mathrm{a}}, 2^{\mathrm{a}}$ e $3^{\mathrm{a}}$ divisões, mencionando os respectivos artigos daquele Tratado. Projeto Resgate Barão do Rio Branco - Colônia do Sacramento e Rio da Prata (1618-1826), AHU_ACL_CU_059, Cx. 3, D. 207.

6. Este rio que já estava registrado, porém, sem nome corresponde ao atual Rio Chapecó.

7. Plano Topográfico, 1784-1788, Biblioteca do Congresso, Washington, vide Kantor (2009: 47).

8. Essas negociações referem-se as trocas da Colônia do Sacramento e às Molucas que, de acordo com Dom Luís Cunha (foi embaixador do governo português e teve influências na elaboração da Carte de l'Amerique Méridionale), seriam as duas grandes moedas de troca a oferecer nas negociações. Essa ideia de negociação de posses territoriais era também compartilhada por D'Anville (Furtado, 2011).

9. Por sistema cultural toponímico compreende-se o conjunto de práticas, costumes e normas (explícitas ou não) que caracterizam a forma como uma determinada sociedade ou instituição adota para nomear os locais. Esse sistema pode diferenciar também ao longo do tempo devido a algum acontecimento ou incorporação de uma nova norma. Como exemplo: a Coroa hispânica empregou com mais ênfase nomes idênticos ou que lembravam cidades e/ou locais da Espanha (Córdoba, por exemplo), bem como a denominação mini e guaçu aos rios, enquanto os lusitanos empregaram mais a hagiotoponímica articulada com nomenclaturas indígenas: São Paulo de Piratininga, por exemplo. 
10. Hagiotoponímica refere-se à toponímia que incorpora no nome dos lugares elementos religiosos (como santos, santidades etc.). Exemplo: São José dos Ausentes, Nossa Senhora do Desterro, São Paulo de Piratininga.

11. No original: "la formación del Estado Nacional argentino fue un processo planificado que implico la "invención" de um território "legítimo" sobre el cual era posible ajercer el domínio".

12. Os departamentos correspondem a uma entidade federativa inferior à entidade do Território Nacional.

13. Para mais informações sobre a publicação deste documento cartográfico no contexto de disputa territorial, ver Moraes (2017).

14. No original: "Declárase nacional el territorio de Misiones cuyo límite al oeste quedará fijado por el cauce principal del Río Aguapey, desde su desembocadura en el Uruguay hasta el Paralelo $28^{\circ}$ de latitud sur y de allí por la línea meridiana hasta el Río Paraná".

15. Registra-se que, somente em 1943, o poder central do Brasil criou um território na referida região. Identificado como Território Federal do Iguaçu, ele teve uma breve duração (apenas três anos).

16. A legislação argentina impedia a comercialização de terras nas proximidades das manchas de ervais para evitar sua destruição.

17. Compete salientar que a concessão de títulos de terras na região do Pampa, foi também uma estratégia para dilatar o poder central, visto que muito dos beneficiados eram também próximos a elite portenha (Bethel, 2001).

18. São Luiz das Missões (atual São Luiz Gonzaga), São Miguel das Missões, Santo Ângelo, Campo Novo, São Borja e Uruguaiana. O viajante realizou duas viagens, uma em 1881 e outra em 1887.

19. Delson ao estudar a criação de vilas e cidades no Brasil Colônia, destaca que a implantação das mesmas "derivava do desejo luso-brasileiro de ampliar os domínios territoriais em detrimento dos espanhóis" (1997: 14). A autora acrescenta, ainda, que muito antes do princípio de uti posseditis servir como instrumento jurídico, ele já era uma prática lusitana.

20. Vale frisar que nas proximidades de Curitibanos, foi o local no qual ocorreu a primeira ofensiva com resultado positivo para o Império contra os farrapos.

21. O viés liberal se manifesta, sobretudo, na inspiração para constituição de uma nova nação. Todavia, o conceito de liberdade não era ampliado até aos cativos, visto que "a fina flor" da República Riograndense era constituída por estancieiros e escravocratas, mantendo-se alinhada ao restante das oligarquias do Império.

22. Brasil, Decreto n.ำ 1.318, de 30 de janeiro de 1854.

23. Conforme pode ser visto em Couto Magalhães (1875: 68) apud Brüggmann (2013: 37-38).

24. Freitag (2007).

25. Para Raffestin (1993), a composição de uma tessitura é feita por linhas e nós que compõem uma "rede", a tessitura.

26. Corresponde a aquele que executa uma ação, a qual integra um projeto ou programa elaborado por um outro agente, dotado de maior capacidade de influência. Este agente com maior capacidade de influência, logo, dotado de mais condições para concretizar projetos, é chamado de agente sintagmático (Raffestin, 1993).

27. A influência da Revolução Industrial, da Revolução Francesa e o desenvolvimento da filosofia iluminista foram experiências históricas que alteraram a concepção e os parâmetros para balizar o desenvolvimento das sociedades e a forma como estas se organizavam. Desse modo, visualiza-se que alguns dos seus vocábulos foram incorporados no pensamento político e social em períodos posteriores, servindo como indicadores de um novo tempo desejado por segmentos sociais que comandavam os órgãos políticos ou faziam uso de instituições políticas.

28. Hobsbawm (1996). 
29. Ver Aranha (2014) e Barão do Rio Branco (2005).

30. Mensagem dirigida a Salvador de Mendonça, datada do ano de 1894: "Salvador [...] Abandonei-o hoje no Senado porque o discurso estava interminável. Cheguei no hotel tive conversa muito agradável sobre o Pepiry, que vale mais que o canal da Nicarágua. A conversa foi com pessoa de maior competência n'este negócio de Pepiry-Sto Antônio." Fonte: Biblioteca Nacional do Brasil. Salvador de Mendonça foi fundador do Clube Republicano, conjuntamente com Quintino e Saldanha Marinho, que divulgavam os ideais do grupo. É indicado como o precursor da aproximação com os EUA antes de tal alinhamento adquirir oficialidade através de convênios e acordos.

31. No original: Así como la bellleza natural de las cataratas del Ú-guazú, com su esplendoroso marcao de flores, de isipós y de orquídeas, bajo del dossel de um cielo espléndido, es inmensamente superior à la beleza del Niágara, encuadrada em la sombría vegetación borel; así también la fuerza de las mil cascatas em que se subdivide el Ú-guazú és por lo menos diez veces mayor que su rival norte-maericana, que el sábio Siemens há estimado em 16.800.000 - dieciséis millones ochocientos mil - caballosvapor. El magnífico paisaje encierra, pues, tesoro inagotable de fuerzas latentes que em dia no lejano transformarán los ingenieros argentinos em manantiales de civilizacion, llevando á través de uma red de cales à todos los âmbitos de la República torrentes de luz, de calor y de fuerza eléctrica recogidos em turbinas al pié de las cascadas. (Basaldúa, 1901: 166 apud Aranha, 2014: 148).

32. Ao final do século XIX foi construída a primeira hidroelétrica no Brasil, situada em Diamantina, utilizando as águas do Ribeirão do Inferno, afluente do Rio Jequitinhonha. No alvorecer do século XX, nas águas do Rio Tietê, na Cachoeira do Parnayba, foi construída pela Light and Power a primeira grande instalação hidroelétrica, com capacidade de fornecer 8.000 cavalos-vapor (Nobre, 2012). Em 1901, a capacidade foi dobrada.

33. O que realizou somente em 1937, durante o Estado Novo (Nobre, 2012).

34. Romário Martins (1874-1949) foi intelectual e político que muito atuou nas práticas de apropriação simbólica da oligarquia paranaense durante o litígio territorial com o Estado de Santa Catarina, sendo contratado pelo Estado do Paraná para produzir a documentação que comprovasse os direitos paranaenses sobre os Campos de Palmas.

\section{RESUMOS}

A constituição da fronteira entre Argentina e Brasil (Questão das Missões/Palmas) é o objeto de estudo do presente trabalho. Dentre os recortes passíveis de se aplicar a este evento, optou-se por abordar as questões relativas ao mapeamento e reconhecimento da linha limítrofe ainda durante o período de domínio colonial, momento no qual o litígio é originado. Esses dados são fundamentais para se compreender a retomada desta querela pelos países latino-americanos. Os interesses políticos, bem como a pertinência da formação territorial e do desenvolvimento econômico são elementos explicativos da retomada deste litígio, os quais também são incorporados ao trabalho.

The formation of Argentina and Brazil's border (Missões/Palmas Issue) is the main object of the present work. Between all applicable approaches for this event, it was decided to address the 
issues related to the mapping and recognition of the borderline still during the colonial domain period, the moment when the dispute was originated. This data is essential to understand the resumption of this complaint by latin-american countries. Political interests, as well as the relevance of territorial formation and economic development are explanatory variables of this dispute's complaint and are also incorporated to this paper.

La constitución de la frontera entre Argentina y Brasil (Cuestión de las Misiones/Palmas) es el objeto del presente trabajo. Entre los recortes que podría aplicar a este evento, se decidió por abordar los problemas relativos al mapeo y el reconocimiento de la línea limítrofe aún durante el período de dominio colonial, cuando se originó la disputa. Estos datos son fundamentales para comprender la reanundación de esta disputa por los países latino-americanos. Los intereses políticos, así como la relevancia de la formación territorial y el desarrollo económico son los elementos de la reanundación de esta disputa, que también se incorporan el trabajo.

La constitution de la frontière entre l'Argentine et le Brésil (quéstion des Missions/Palmes) est le sujet d'études de ce travail. Parmi les découpes possibles d'application a cet événement, il fût choisi d'aborder les questions relatives au tracé et à la reconnaissance de la ligne de démarcation encore en vigueur durant la période coloniale, moment dans lequel le litige est instauré. Ces données sont fondamentales pour comprendre la reprise de cette querelle par les pays latinoaméricains. Les interêts politiques, ainsi que la pértinence de la formation territorialle et du devellopement économique sont des éléments éxplicatifs de la reprise de ce litige, lesquels ont aussi été incorporés a ce travail.

\section{ÍNDICE}

Palabras claves: frontera, formación territorial, cuestión de las Misiones/Palmas

Palavras-chave: fronteira, formação territorial, questão das Missões/Palmas

Índice cronológico: 1880-1940

Mots-clés: frontière, formation territorialle, quéstion des Missions/Palmes

Índice geográfico: Missões/Palmas, Argentina e Brasil

Keywords: border, territorial formation, Missões/Palmas issue

\section{AUTOR}

\section{CRISTINA DE MORAES}

Doutora em Geografia

Pós-doutoranda no Programa de Pós-Graduação de Ciências Humanas e Sociais - Faculdade de Filosofia e Letras/Universidade de Buenos Aires

Professora colaboradora no Centro de Ciências Humanas e da Educação (FAED), Universidade do

Estado de Santa Catarina (UDESC)

E-mail: cris2.moraes@gmail.com 